\title{
The influence of cellulose, starch and different sources of nitrogen on the growth of rumen ciliate protozoon Epidinium ecaudatum in vitro
}

\author{
T. Michałowski \\ ${ }^{\prime}$ Department of Vertebrate Physiology, Zoological Institute, \\ Warsaw University \\ Żwirki $i$ Wigury 93,02-089 Warszawa, Poland \\ The Kielanowski Institute of Animal Physiology and Nutrition, \\ Polish Academy of Sciences \\ 05-110 Jablonna, Poland
}

(Received 7 June 1995; accepted 22 August 1995)

\begin{abstract}
The rumen ciliate Epidinium ecaudatum was grown in vitro in one species culture. The culture medium consisting of salt solution, powdered hay and wheat gluten provided appropriate conditions for maintenance of the protozoa. The population density was influenced by the proportion of cellulose, starch and urea in the culture medium as well as by the solubility of protein. The ciliates did not require rumen fluid for the growth.
\end{abstract}

KEY WORDS: Epidinium ecaudatum, rumen ciliates, cultivation

\section{INTRODUCTION}

Epidinium ecaudatum is one of the most common species of rumen ciliates. It belongs to the "large Ophryoscolecidae" and possesses high cellulolytic activity (Coleman, 1985). This may suggest that this species of protozoa has an involvement in the supply of energy from indigestible carbohydrates to the host.

This study was carried out in order to provide some information concerning the possibility of maintenance of Epidinium ecaudatum in vitro in one species

\footnotetext{
${ }^{1}$ Corespondence address
} 
culture and relevant importance of various nutritional factors required for the development of a population of these organisms.

\section{MATERIAL AND METHODS}

\section{Organisms, culture media and culture conditions}

The ciliates originated from the rumen of cattle fed a hay-concentrate diet. The method for the initial inoculation of mixed cultures of protozoa and the preparation of a one species culture were the same as described previously (Michałowski et al., 1989).

Four types of salt solution (Table 1) were used to form the liquid part of the culture medium. Other components of the medium, treated as food, were: powdered hay, barley starch (Whelan, 1955), wheat gluten (Klein, 1933; Pace, 1955), soluble casein (BDH) and urea (POChem). Insoluble casein was prepared by precipitation with $10 \%$ TCA.

The protozoa were cultured anaerobically $\left(100 \% \mathrm{CO}_{2}\right)$ according to routine methods established in this laboratory (Michałowski, 1975; Michałowski et al., 1991).

The ciliates were fed every day and every fourth day they were transferred into fresh medium.

TABLE 1

The chemical composition of salt solution $(\mathrm{g} / \mathrm{l})$ used for cultivation of Epidinium ecaudatum

\begin{tabular}{lllll}
\hline Ingredient & $\mathrm{A}$ & $\mathrm{B}$ & $\mathrm{C}$ & $\mathrm{D}$ \\
\hline $\mathrm{K}_{2} \mathrm{HPO}_{4}$ & 6.3 & 4.9 & 0.0 & 0.0 \\
$\mathrm{KH}_{2} \mathrm{PO}_{4}$ & 5.0 & 3.8 & 1.0 & 0.0 \\
$\mathrm{Na}_{2} \mathrm{HPO}_{4} \cdot 12 \mathrm{H}_{2} \mathrm{O}$ & 0.0 & 0.0 & 0.0 & 9.3 \\
$\mathrm{NaHCO}_{3}$ & 0.0 & 6.6 & 5.0 & 9.8 \\
$\mathrm{KCl}$ & 0.0 & 0.0 & 0.0 & 0.56 \\
$\mathrm{NaCl}$ & 0.65 & 0.49 & 6.0 & 0.47 \\
$\mathrm{CaCl}$ & 0.09 & 0.07 & 0.2 & 0.08 \\
$\mathrm{MgSO}_{4} \cdot 7 \mathrm{H}_{2} \mathrm{O}$ & 0.09 & 0.07 & 0.2 & 0.0 \\
$\mathrm{CH}_{3} \mathrm{COONa}_{2}$ & 0.75 & 0.0 & 0.0 & 0.0 \\
$\mathrm{pH}$ & 6.84 & 7.53 & 7.76 & 8.52 \\
\hline
\end{tabular}

A - "caudatum type", B - "simplex type" salt solution (Coleman et al., 1972)

C - "Hungate type" salt solution (Hungate, 1942)

D - artificial saliva (McDougal, 1948) 


\section{Experimental cultures, sampling and counting}

All cultures were initiated by inoculation of the ciliate suspension $(20 \mathrm{ml})$ into Erlenmeyer flasks containing $20 \mathrm{ml}$ of culture salt solution and appropriate food. Three cultures were always run simultaneously in relation to any factor studied. Each culture experiment lasted 30 days.

Samples for the counting of protozoa and bacteria were taken on transfer days (see above) and were fixed with an equal volume of $4 \%$ formaldehyde solution.

Ciliate number was estimated according to Michałowski (1975) and the bacteria counte dwith the use of a Thoma counting chamber.

\section{Statistic}

The results obtained were analysed using Student's t-test.

\section{RESULTS}

The ciliates survived only in "caudatum type" salt solution irrespective to the composition of food. On the other hand they did not survive when only hay was supplied irrespective of the chemical composition of the salt solution. Protozoa were able to survive for many months when the hay was supplemented with an appropriate dose of wheat gluten, microcrystalline cellulose or barley starch. An increase in cellulose content was followed by an increase in the population density of Epidinium ecaudatum while the number of bacteria remained unchanged (Table 2). Pure barley starch supported growth of Epidinium ecaudatum up to a dose of $0.1 \mathrm{mg} / \mathrm{ml} / \mathrm{d}$ (Table 3). An increase in the dose of starch above this value caused a decrease in the population density of ciliates. Contrary to that the number of bacteria increased from $11.5 \times 10^{7} / \mathrm{ml}$

TABLE 2

The population density of Epidinium ecaudatum and bacteria in the cultures fed with control diet (hay $0.6 \mathrm{mg} / \mathrm{ml} / \mathrm{d}+$ wheat gluten $0.15 \mathrm{mg} / \mathrm{ml} / \mathrm{d}$ ) alone or supplemented with different doses of microcrystalline cellulose (mean values \pm standard error; $\mathrm{n}=3$ )

\begin{tabular}{lcc}
\hline $\begin{array}{l}\text { Cellulose dose } \\
\mathrm{mg} / \mathrm{ml} / \mathrm{d}\end{array}$ & $\begin{array}{c}\text { Ciliates } \\
\mathrm{x} 10^{2} / \mathrm{ml}\end{array}$ & $\begin{array}{c}\text { Bacteria } \\
\mathrm{x} 10^{7} / \mathrm{ml}\end{array}$ \\
\hline 0 (Control) & $4.1 \pm 0.24$ & $9.9 \pm 0.34$ \\
0.05 & $4.6 \pm 0.28$ & $10.6 \pm 0.29$ \\
0.15 & $6.1 \pm 0.20^{\mathrm{x}}$ & $9.7 \pm 0.25$ \\
0.25 & $6.8 \pm 0.48^{\mathrm{x}}$ & $10.2 \pm 0.31$ \\
\hline
\end{tabular}

${ }^{x}$ values differ significantly $(\mathrm{P}<0.001)$ from the control value 
TABLE 3

The number of Epidinium ecaudatum and bacteria in the cultures fed with control diet (hay $0.6 \mathrm{mg} / \mathrm{ml} / \mathrm{d}$ + wheat gluten $0.15 \mathrm{mg} / \mathrm{ml} / \mathrm{d}$ ) alone or supplemented with different doses of barley starch (mean values standard error; $\mathrm{n}=3$ )

\begin{tabular}{lcc}
\hline $\begin{array}{l}\text { Starch dose } \\
\mathrm{mg} / \mathrm{ml} / \mathrm{d}\end{array}$ & $\begin{array}{c}\text { Ciliates } \\
\mathrm{x} 10^{2} / \mathrm{ml}\end{array}$ & $\begin{array}{c}\text { Bacteria } \\
\mathrm{x} 10^{7} / \mathrm{ml}\end{array}$ \\
\hline $0($ Control $)$ & $1.9 \pm 0.18$ & $11.5 \pm 0.46$ \\
0.05 & $2.6 \pm 0.18$ & $12.7 \pm 0.37$ \\
0.10 & $3.2 \pm 0.37^{\times}$ & $13.0 \pm 0.52$ \\
0.15 & $2.7 \pm 0.28$ & $14.4 \pm 0.60$ \\
0.20 & $2.6 \pm 0.46$ & $14.8 \pm 0.87$ \\
0.30 & $2.4 \pm 0.44$ & $13.9 \pm 0.60$ \\
\hline
\end{tabular}

${ }^{x}$ value differs significantly $(\mathrm{P}<0.001)$ from the control value

to $14.8 \times 10^{7} / \mathrm{ml}$ when the supplementary dose of starch was increased from 0.1 to $0.3 \mathrm{mg}$ per $\mathrm{ml}$ per day. There was no correlation between the number of ciliates and bacteria in the cultures. Pure barley starch eliminated ciliates from the cultures within 12-16 days when was supplied at the rate of $0.3 \mathrm{mg} / \mathrm{ml} / \mathrm{d}$.

No correlation was observed $(\mathrm{r}=0.648 ; \mathrm{P}>0.05)$ between the number of Epidinium ecaudatum and wheat gluten dose (Table 4) while the number of bacteria increased when wheat gluten dose increased $(\mathrm{r}=0.940 ; \mathrm{P}<0.01)$. The ciliates did not survive the replacement of wheat gluten with urea in doses exceeding $0.06 \mathrm{mg} / \mathrm{ml} / \mathrm{d}$. A urea concentration of $0.18 \mathrm{mg} / \mathrm{ml}$ eliminated protozoa from the cultures within 8 days (Figure 1). The number of ciliates in the cultures fed with hay, cellulose and soluble or insoluble casein are presented in Figure 2. The population density of Epidinium ecaudatum in cultures receiving insoluble casein was approximately 1.5 times greater than in the cultures fed with soluble form of this protein $(\mathrm{P}<0.01)$.

TABLE 4

The number of Epidinium ecaudatum and bacteria in the cultures fed with hay $(0.6 \mathrm{mg} / \mathrm{ml} / \mathrm{d})$ and cellulose $(0.25 \mathrm{mg} / \mathrm{ml} / \mathrm{d})$ alone or supplemented with different doses of wheat gluten

\begin{tabular}{lcc}
\hline $\begin{array}{l}\text { Wheat gluten dose } \\
\mathrm{mg} / \mathrm{ml} / \mathrm{d}\end{array}$ & $\begin{array}{c}\text { Ciliates } \\
\mathrm{x} 10^{2} / \mathrm{ml}\end{array}$ & $\begin{array}{c}\text { Bacteria } \\
\mathrm{x} 10^{7} / \mathrm{ml}\end{array}$ \\
\hline 0 & $3.6 \pm 0.20$ & $9.1 \pm 0.14$ \\
0.025 & $3.9 \pm 0.23$ & $10.1 \pm 0.16$ \\
0.05 & $3.1 \pm 0.23$ & $10.6 \pm 0.11$ \\
0.10 & $3.9 \pm 0.28$ & $10.6 \pm 0.22$ \\
0.15 & $4.7 \pm 0.22$ & $10.9 \pm 0.19$ \\
0.20 & $3.5 \pm 0.39$ & $11.0 \pm 0.25$ \\
0.25 & $4.1 \pm 0.40$ & $12.2 \pm 0.17$ \\
0.30 & $5.2 \pm 0.67$ & $13.2 \pm 0.21$ \\
\hline
\end{tabular}




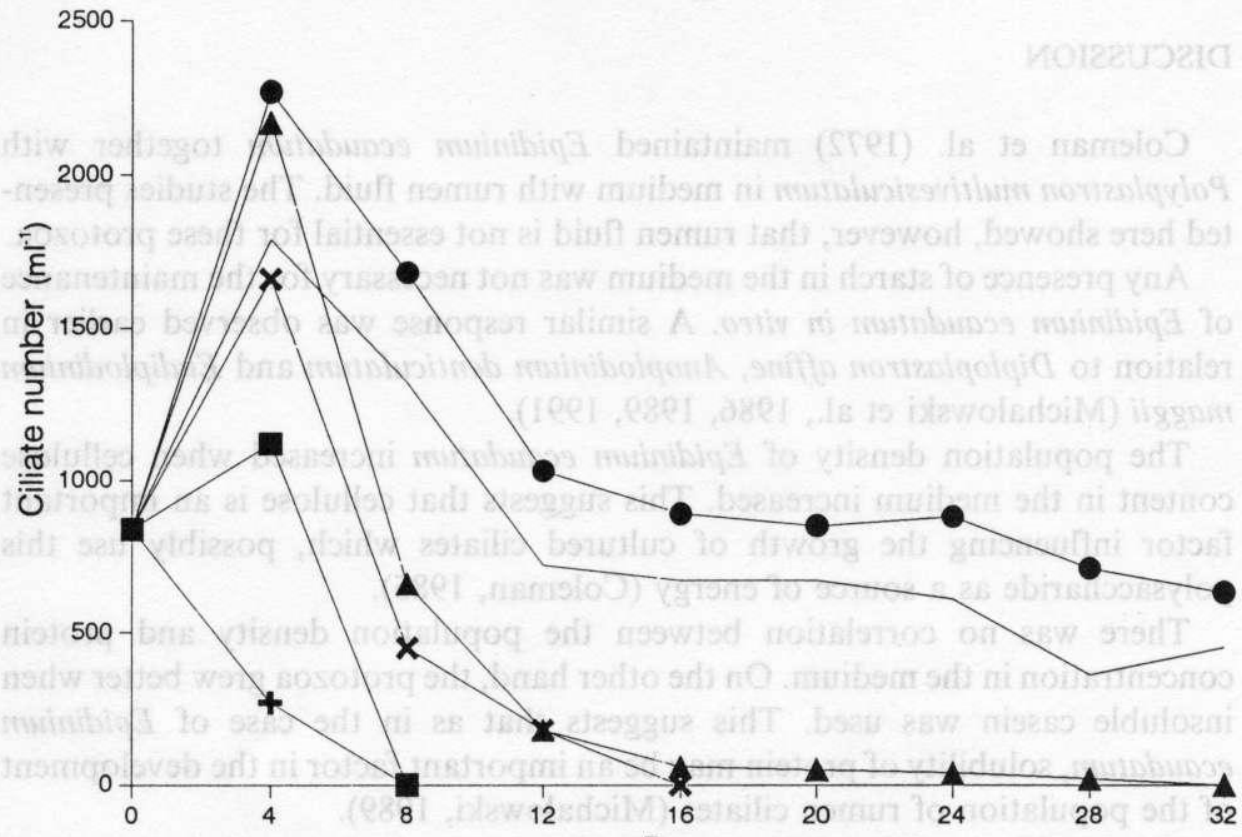

Days

Figure 1. The changes in number of Epidinium ecaudatum cultured in vitro and fed with hay $(0.6 \mathrm{mg} / \mathrm{ml} / \mathrm{d})$ and barley starch $(0.1 \mathrm{mg} / \mathrm{ml} / \mathrm{d})$ alone $(-)$ or supplemented with urea in the ratio of $0.06(\bullet), 0.08(\mathbf{\Lambda}), 0.12(\mathrm{x}), 0.18(\mathbf{-})$ and $0.36 \mathrm{mg} / \mathrm{ml} / \mathrm{d}(+)$

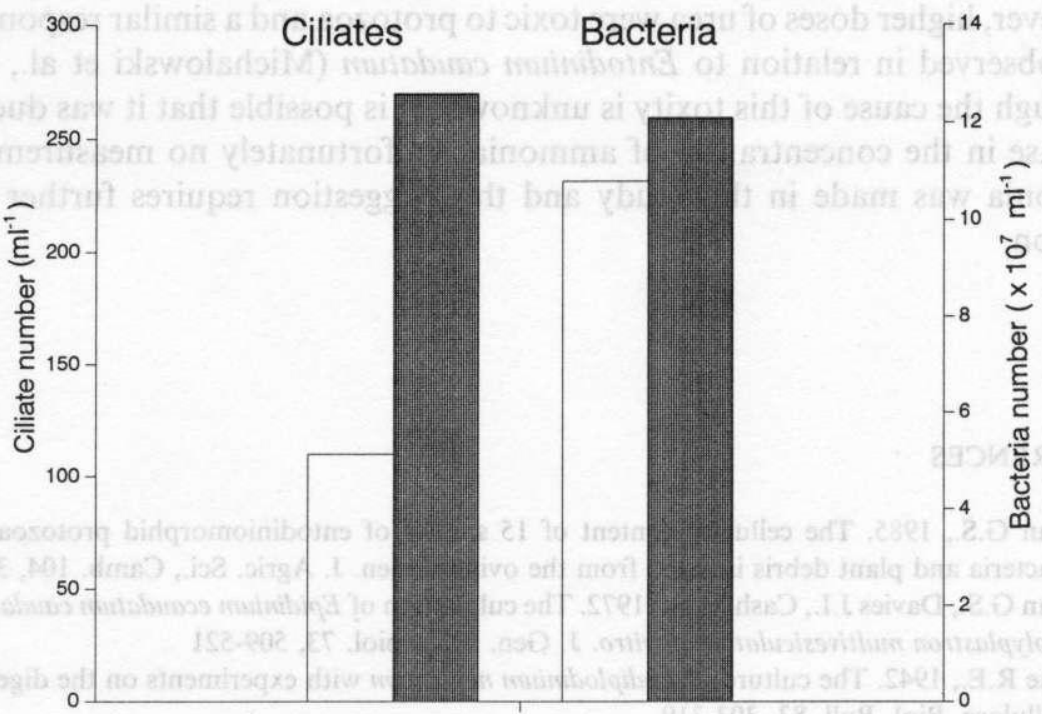

Figure 2. Mean number of Epidinium ecaudatum and bacteria in the cultures fed with hay $(0.6 \mathrm{mg} / \mathrm{ml} / \mathrm{d})$ and cellulose $(0.25 \mathrm{mg} / \mathrm{ml} / \mathrm{d})$ supplemented with soluble ( $\square$ ) or insoluble ( ) casein $(0.125 \mathrm{mg} / \mathrm{ml} / \mathrm{d})$ 


\section{DISCUSSION}

Coleman et al. (1972) maintained Epidinium ecaudatum together with Polyplastron multivesiculatum in medium with rumen fluid. The studies presented here showed, however, that rumen fluid is not essential for these protozoa.

Any presence of starch in the medium was not necessary for the maintenance of Epidinium ecaudatum in vitro. A similar response was observed earlier in relation to Diploplastron affine, Anoplodinium denticulatum and Eudiplodinium maggii (Michałowski et al., 1986, 1989, 1991).

The population density of Epidinium ecaudatum increased when cellulose content in the medium increased. This suggests that cellulose is an important factor influencing the growth of cultured ciliates which, possibly use this polysaccharide as a source of energy (Coleman, 1985).

There was no correlation between the population density and protein concentration in the medium. On the other hand, the protozoa grew better when insoluble casein was used. This suggests that as in the case of Epidinium ecaudatum, solubility of protein may be an important factor in the development of the population of rumen ciliates (Michałowski, 1989).

Urea positively affected the number of protozoa when supplied at a rate of $0.06 \mathrm{mg} / \mathrm{ml} / \mathrm{d}$. An explanation of this finding could be the increase in the total nitrogen content of the medium and more intensive development of bacteria as the rumen ciliates are unable to directly utilize urea (Onodera et al., 1977). However, higher doses of urea were toxic to protozoa and a similar response was also observed in relation to Entodinium caudatum (Michałowski et al., 1987), although the cause of this toxity is unknown. It is possible that it was due to an increase in the concentration of ammonia. Unfortunately no measurement of ammonia was made in this study and this suggestion requires further investigation.

\section{REFERENCES}

Coleman G.S., 1985. The cellulase content of 15 species of entodiniomorphid protozoa, mixed bacteria and plant debris isolated from the ovine rumen. J. Agric. Sci., Camb. 104, 349-360

Coleman G.S., Davies J.I., Cash M.A., 1972. The cultivation of Epidinium ecaudatum caudatum and Polyplastron multivesiculatum in vitro. J. Gen. Microbiol. 73, 509-521

Hungate R.E., 1942. The culture of Eudiplodinium neglectum with experiments on the digestion of cellulose. Biol. Bull. 83, 303-319

Klein G., 1933. Handbuch der Pflanzenanalyse. Vien, Springer Verlag, pp. 333-354

McDougal E., 1948. Studies on ruminant saliva. 1. The composition and output of sheep's saliva. Biochem. J. 43, 99-109 
Michałowski, T. 1975. The effect of certain feedingstuffs on rumen ciliate protozoa in vitro. J. Agric. Sci., Camb. 85, 151-158

Michałowski T., 1989. Importance of protein solubility and nature of dietary nitrogen for the growth of rumen ciliates in vitro. In: J.V. Nolan, R.A. Leng, D.I. Demeyer (Editors), The Roles of Protozoa and Fungi in Ruminant Digestion. Penambul Books, Armidale, NSW, Australia, pp. 223-231.

Michałowski T., Landa I., Muszyński P., 1989. Factors influencing the development of population of rumen ciliates Anoplodinium denticulatum in vitro. Acta Protozool. 28, 273-283

Michałowski T., Landa I., Muszyński P., Szczepkowski P., 1987. The influence of non-protein-nitrogen on the growth of rumen ciliate Entodinium caudatum in vitro. Acta Protozool. 26, 329-334

Michałowski T., Muszyński P., Landa I., 1991. Factors influencing the growth of rumen ciliates Eudiplodinium maggii in vitro. Acta Protozool. 30, 115-120

Michałowski T., Szczepkowski P., Muszyński P., 1986. The nutritive factors affecting the cultivation of the rumen ciliate Diploplastron affine in vitro. Acta Protozool. 25, 419-426

Onodera R., Yamaguchi H., Eguchi C., Kandatsu M., 1977. Limits of survival of the mingled rumen bacteria in the washed cell suspension of rumen ciliate protozoa. Agric. Biol.Chem. 41, 2465-2466

Pace J., 1955. Seed proteins. In: K. Peach, M.V. Tracey (Editors), Modern Methods of Plant Analysis. Springer Verlag, Berlin, Göttingen, Heidelberg, pp. 69-105

Whelan W.J., 1955. Starch, glycogen, fructosans and similar polysaccharides. In: K. Peach, M.V. Tracey (Editors). Modern Methods of Plant Analysis. Springer Verlag, Berlin, Göttingen, Heidelberg, pp. 145-196

\section{STRESZCZENIE}

Wpływ celulozy, skrobi i różnych źródeł azotu na rozwój orzęska żwaczowego Epidinium ecaudatum in vitro

Orzęski żwaczowe Epidinium ecaudatum hodowano in vitro jako jednogatunkowe kultury. Stwierdzono, że pożywka złożona $\mathrm{z}$ odpowiedniego roztworu soli, mielonego siana i glutenu pszennego zapewniała właściwe warunki do hodowli pierwotniaków. Gęstość populacji orzęsków zależała od zawartości celulozy, skrobi i mocznika w pożywce. Na liczebność pierwotniaków wpływała również rozpuszczalność białka pokarmowego. Orzęski nie wymagały uzupełnienia pożywki płynem żwaczowym. 